VII. On some new species of Butterfies from Tropical and Extra Tropical South Africa. By Roland Trimen, F.R.S., F.L.S., Curator of the South-African Museum, Cape Town.

[Read March 6th, 1895.]

Plate V.

THReE of the species here described and figured, viz., Ypthima mashuna, Mycalesis selousi, and Acræa induna, have been received from Mashunaland only; another, Capys disjunctus, from Mashunaland, Transvaal, and Natal; and the remaining two, Lycæna nubifer and Iolaus æmulus, solely from Natal.

Capys disjunctus is of special interest, both as a new member of a hitherto monotypic genus, and as an instance of remarkable and unexpected disparity between the sexes; and Lycæna nubifer finds no nearer ally than L. cordata (E. M. Sharpe), a native of the very remote territory of Kavirondo, to the east of Lake Nyanza.

\title{
Family NYMPHALID王。
}

\section{Subfamily SATYRIN}

\section{Ypthima mashuna, sp. n. (Plate V., fig. 1.)}

Exp. al. (ô) 1 in., $2 \frac{1}{2}-4 \frac{1}{2}$ lin.; ( $q$ ) 1 in., $2-3 \frac{1}{2}$ lin.

o. Obscure fuscous-grey; forewing with a small subapical ocellus; hindwing without marking. Forewing: ocellus small, vertically oblong, indistinct, bipupillate with sub-metallic whitish, very obscurely ringed with yellowish-grey. Underside : Pale grey or hoary-grey, more or less closely striolated with fuscousbrownish along costal and apical border of forewing and throughout hindwing. Forewing: Field somewhat paler and more brownish than on upperside; subapical ocellus better defined, and in a more distinct ring. Hindwing: On disk a post-median series of TRANS. ENT. SOC. LOND. 1895.-PART II. (JUNE.) 
three minute unipupillate ocelli (in some examples obsolete), coloured like the ocellus in forewing, the 1st and 2nd situated respectively above and below radial nervule, and the 3rd below 2 nd median nervule; all these ocelli, but especially the 1st and 2nd, are remote from hindmargin.

9. Paler; ocellus of forewing larger, not so narrow, its yellowish ring much more distinct and, in one example, sharply defined.

This small and extremely dusky Ypthima is, perhaps, nearer to $Y$. asterope (Klug) than to any other congener, but differs notably in its smaller size, darker colour, reduced ocellus in forewing, total want of paler space and dark encircling line round that ocellus; and, on the underside, in the absence of striolation in the forewing except on the costal and apical margin, and the totally diverse positions of the minute ocelli in its hindwing, as well as the absence of any trace of transverse striæ.

The seven $\delta$ t (one a dwarf not exceeding 1 in. in expanse) and three $q q$ before me are in poor condition, and the antennæ are present in two of the $q q$ only; but these organs are extremely short-about 2 lin. only in length-and with a short, rather thick, very blunt club, while in $Y$. asterope, + , they are fully 3 lin., and with a narrow, elongate, gradually-formed club. The terminal joint of the palpi is also much shorter in both sexes than it is in asterope.

I was not acquainted with this butterfly until April, 1894, when I received three specimens of the from Mr. J. M. Hutchinson, on behalf of Mr. G. A. K. Marshall, with the note that the latter gentleman had taken them at Fort Charter and the Hanyani River, in Mashunaland. The other examples followed in June and July; and among them is the largest ot, specially recorded by Mr. Marshall as captured at Salisbury on 23rd April.

Some specimens since received were taken at Salisbury in July, August, and September; and Mr. Marshall notes the species as very local, frequenting only swampy open ground, and in flight like $Y$. asterope. On the road from Fort Charter to Salisbury it seemed rather abundant, but round Salisbury itself a few examples only were met with.

Hab. Mashunaland; Fort Charter, Salisbury, and Hanyani River (G. A. K. Marshall). 


\section{Mycalesis selousi, sp. n. (Plate V., figs. 2, 2a.)}

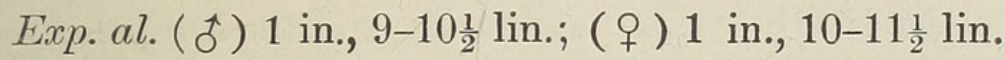

ô. Brownish-grey, with a tinge of yellow-ochreous; hindmargins narrowly pale grey, with two parallel darl grey subterminal hair lines; no ocelli, but in three (out of four) examples a small indistinct fuscous spot marking the usual position of an ocellus between 1 st and 2nd median nervules of foreuing; ground-colour of same wing slightly paler subapically. Citia pale grey. Underside: Soft pale grey, with a pale violaceous tinge, finely (and beyond middle more sparsely) hatched and irrorated with brownish-grey; common premedian and postmedian streaks thin, irregularly dentaiesinuate, brown, the former (indistinct in forewing) faintly inwardly, the latter more strongly outwardly, edged narrowly with whitish-yellow. Forewing: subapical ocellus, between radial nervules, indicated by a very small or minute white spot; lower ocellus, between 1st and 2nd median nervules, very small but complete, the white pupil conspicuous but the yellowish ring indistinct. Hindwing: postmedian line more irregular than in forewing; ocelli of discal series very small or minute, their rings not perceptible, the 3 rd of the normal 7 wanting, and the 2 nd represented by a white dot only.

․ Like of ; but in forewing the fuscous spots representing the two ocelli are (in two out of three specimens) better expressed, and there is between them some ill-defined paler clouding.

This species appears to belong to the Safitza group; the of has the same sexual badges; viz., in the forewing, the sac about the middle of the submedian nervure, and (on the underside) the wide, glossy, inner-marginal space; and, in the hindwing, the glossy costal border and tuft of hair on subcostal nervure. The subcostal, median, and submedian nervures of the forewing are all swollen at the base.

This Mycalesis, on the whole, comes nearest to $M$. leptoglena, Karsch,* but differs (judging from the description and figure of that species) on the underside in (1) the general hatching and irroration, (2) the sinuatedentate irregularity of the postmedian streak (especially in the hindwing), (3) only two ocelli (instead of five) in the forewing, and total absence of the pale outer circles of all ocelli in both wing's so conspicuous in M. leptoglena,

* Berl. Ent. Zeits. xxxviii., p. 208, No. 95, pl. v., fig. 7 ( $q$ ). Hab. Bismarckburg, Togoland. 
(4) want of the well-marked common submarginal streak not far beyond ocelli, and (5) much paler and more violaceous-grey tint.

The four of of and three $q$ o here described were taken by Mr. F. C. Selous, in Mashunaland, in 1882. The dates of capture were not recorded, but the very suppressed condition of the ocelli makes it not improbable that these specimens belong to a winter or dry-season brood. It is with great pleasure that I dedicate this species to my friend, Mr. F. C. Selous, who has done so much to make known the butterflies of Tropical South Africa.

On writing to Mr. G. A. K. Marshall at Salisbury about this Mycalesis, he was not long in finding it out, and soon sent me a series, taken in June, 1894, chiefly on the Hanyani River, but also at Hartley, Enterprise Camp (about twenty miles east of Salisbury), and the Umfuli River. In two $q$ f from Hanyani River, taken on 15 th June, the ocelli on the underside are decidedly larger, and with less indistinct rings.

Mr. Marshall notes that this Mycalesis frequents the thick "mahobohobo" (or "wild loquat") bush, where there is good shade; it keeps in its shadiest spots during the day, but towards sundown becomes more lively, and may be seen flitting about in the long grass. On two occasions, however, he observed it at mid-day flying round the tops of the trees, and settling now and then.

Hab. Mashunaland (F. C. Selous), Hanyani River, Hartley, Enterprise Camp, and Umfuli River (G. A. K. Marshall).

Subfamily ACR $\mathbb{E I N}$ Æ.

Acræa induna, sp. n. (Plate V., figs. 3, 3a.)

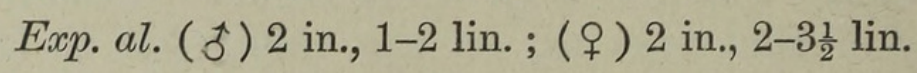

Allied to $A$. caldarena, Hewits., and $A$. cheribula, Oberth.*

ot. Ochreous-yellow, strongly suffused with brick-red over all basal area to beyond middle in both wings, and spotted with black; forewing with broad black patch at apex; hindwing with a moderately

Études d'Ent. xvii., p. 19, pl. ii., fig. 16 (1893). Hab. Lake Tanganyika. 
wide, yellow-spotted, black border along hindmargin. Forewing: brick-red suffusion fading into the ochreous-yellow at about, or rather beyond, middle; a spot in discoidal cell, just above origin of 1st median nervule, and another at extremity of cell ; between the latter and posterior angle two smaller spots obliquely placed, of which the lower is obsolescent in one of three examples, and wanting in another ; in one example, a spot below median nervure, a little before origin of 1st median nervule; base narrowly black ; apical black 5 lines broad on costa, and extending downward as far as 2nd median nervule (just above which it encloses, in two examples, a spot of the ground-colour) ; thence runs a linear hindmarginal black edging to posterior angle, emitting inwardly short nervular and internervular rays; costa with a linear black edging. Hindwing: a sub-basal curved series of five spots (of which the 2nd in discoidal cell is furthest from base and remote from the subcostal first spot) ; space between this series and base, except the subcostal and median nervures, dusky-blackish, set with yellowishwhite hairs ; an unbroken discal series of nine spots, angulated at 3rd median nervule, and thence bisinuated to inner margin rather before middle; of these spots (which are irregularly subcordate or sublunulate in form), the 1st, 6th, and 9 th are nearer to base than the rest, the two former being also, with the 7th, the largest; hindmarginal border of even width throughout, except where it narrows to anal angle, emitting inwardly short black nervular rays, and enclosing seven rather small ochreous-yellow spots, of which the upper three are more or less obsolescent; brick-red suffusion from basal area outward, variable in extent, in one example not strong beyond discal spots, in another strong, and, in the third, reaching to hindmarginal border ; in this last example only there is some fuscous clouding outwardly, bounding spots 6 to 8 of discal series. Cilia fuscous, mixed with whitish towards anal angle of hindwing. UNDERSIDE : Hindwing, and narrow costal border and wide apical area of forewing, very pale creamy-yellowish, with fine black neuration and wide ochraceous inter-nervular stripes towards the borders; spots as on upperside; hindwing with a basal blotch and median fascia of rose-pink. Forewing : field as on upperside, but paler ; a black spot on costa at base. Hindwing: a black spot on costa close to base ; rose-pink basal blotch partly on costal curve, and partly between median and submedian nervures; sub-basal and discal series of spots as on upperside, but the space between them occupied by a fascia of rose-pink, interrupted by pale yellowish lines along the nervules; spots in hindmarginal border greatly enlarged, broadly lunate, white, tinged with yellowish, the black of the border reduced to a linear edging encircling each spot. 
In this species both sexes are distinguishable from A. caldarena by (1) broader and more rounded wings, (2) absence in the forewing of the subcostal series of small black spots beyond the discoidal cell, (3) position of spot below first median nervule of forewing further from the base than the spot above it, (4) position of 4th spot in discal series of hindwing furthest from base of all the spots, instead of being near the extremity of the discoidal cell, (5) total absence, on both surfaces, of subbasal disco-cellular spot in hindwing, and (6) rosy-red median colouring forming a fascia between the rnore regular premedian and discal series of spots on the underside of hindwing.

The of is, further, very distinct from the of caldarena in colouring, being ochreous-yellow, strongly and widely suffused with brick-red, instead of very pale creamyochreous, tinged and shot with pink; (2) the hindmarginal border of the hindwings is much broader; and (3) there is strong and well-defined black basal clouding, in place of a faint fuscous suffusion, in the hindwings.

The $q$ is very similar to the larger and darker examples of the $q$ caldarena, but (1), in the forewing, the basal fuscous is barely traceable, and (2) the discal field is very much paler; while (3), in the hindwing, the black basal suffusion, instead of being generally distributed, is as restricted as in the $\delta$.

Judging from M. Oberthür's figure, the $\delta$ is nearer to A. cheribula than to $A$. caldarena, but differs in (1) the position and regularity of the two transverse series of spots in the hindwing, and, on the underside (2), in wanting altogether the three large basal spots and the superior subterminal disco-cellular spot. The warm colouring of the wings, the blackish basal clouding on their upperside, and the arrangement of the two transverse series of spots on the underside of the hindwings, all resemble the corresponding features in A. anacreon, Trim.; and, singularly enough, the abdomen is not coloured as in the of caldarena, but as in the of anacreon, being black above, with six creamy-yellow spots on each side, and with the extremity ochre-yellow.

Mr. G. A. K. Marshall discovered this butterfly in Mashunaland, and I received from him the three of $\delta$ and two of above described in June, 1894. He wrote that he noticed the insect only about a clump of isolated granite "kopjes" some three miles from Salisbury, and that, 
like $A$. caldarena, it seemed particularly partial to spots where the long "Tambookie grass" grew. Its flight was a great deal slower than that of caldarena, and, indeed, the slowest of any member of the genus observed by Mr. Marshall. As far as the captor remembered, A. induna first appeared towards the end of January, and disappeared about the middle of March. A pair was subsequently captured by Mr. Marshall in the Mazoe Valley, near Salisbury, on the 15th October.

Hab. Mashunaland, Salisbury (G. A. K. Marshall).

\section{Family LYCANIDA.}

\section{Lycæna nubifer, sp. n. (Plate V., figs. 4, 4a.)}

Exp. al. ( f ) 1 in., 2-3 lin.; (q) 1 in., 2-3 lin.

Allied to L. cordata (E. M. Sharpe).*

o. Cupreous-brown, with a general violaceous gloss; a fuscous line on hindmarginal edge; cilia fuscous, indistinctly and unequally marked with white between nervules. Frorewing: a very large, roughly heart-shaped, velvety-black patch, thinly edged with bluishviolaceous scales, on upper discal area, placed obliquely between 2nd subcostal and 2nd median nervules, and with its narrower end nearest apex, while the upper lobe of its broader end is just at extremity of discoidal cell. Hindwing : tail at extremity of 1st median nervule rather long, twisted spirally, rather wide, fuscous, edged and tipped with white; on hindmargin, above 1st median nervule, an indistinct fuscous spot, and below it a faint trace of another similar spot. UNDERSIDE: Hindwing and broad apical area of forewing brownish-grey, crossed transversely by darker submacular marlings edged (in hindwing very conspicuously) with white on both sides ; inner marginal, lower discal, and disco-cellular area of forewing pale dull brownish-ochre-yellow. Forewing: base tinged with fuscous ; a very short white edging on costa close to base ; in discoidal cell, two or three white dots obliquely placed close to base, a subreniform median slightly browner, thinly fuscous- and white-edged spot, and a larger, less complete terminal marking (open superiorly and inferiorly); above these cellular markings two or three small white spots on costa, continuous of their white edgings ; beyond middle, a confluent series of five or six dark grey fuscous- and white-edged spots, of which the 5th and 6th are narrower and much fainter than the rest, the 6 th, below 1st median

* Proc. Zool. Soc. Lond., 1891, p. 636, pl. xlviii., fig. 4. 
nervule, being obsolete in one specimen; external white edge of this submacular series diffuse; hindmarginal border rather widely brownish-grey, with an external series of darker, inwardly whiteedged internervular spots very faintly indicated. Hindwing : base clouded with fuscous, and bearing three imperfect small round white-edged spots ; a larger and very distinct similar round spot on costa before middle; median and terminal disco-cellular spots as in forewing, but darker, and the latter spot partly confluent with the 4th and 6th of the eight spots forming the very irregular confluent discal series from costa to inner margin; between median cellular spot and inner margin, traces of two similar smaller spots ; immediately bounding the discal series externally is a conspicuous whitish band, unevenly dentate along its outer edge ; on hindmargin, a conspicuous round black spot, outwardly edged with iridescent scales, above 1st median nervure, and another below it; above these, traces of a series of fuscous, internally whitish-edged spots.

9. Ground-colour paler, dull ochre-yellow, but, in the forewing, shot with a strong pinkish-violaceous gloss from base to beyond middle, and marked with fuscous spots corresponding in position to those on the underside of that wing. Forewing: costa and hindmargin bordered with dull fuscous, the latter rather broadly; first disco-cellular spot very small in one specimen, and scarcely visible in the second; base dusky. Hindwing: basal and costal area widely dusky; faint traces of two cellular spots, but none of discal series; two hindmarginal spots much more distinct than in $\hat{\delta}$, and with a few iridescent scales. Cilia regularly white-marked in forewing and in upper half of hindwing. UNDERSIDE: As in $\delta$; but, in one example, with the white markings of the hindwing much reduced and a good deal replaced by brownish-grey ; while, in the other, not only are those markings very distinct (though not quite so wide as in $\delta$ ), but the hindmarginal series of spots is in both wings distinct, as well as both the inner and outer white edgings of these spots, the inner edgings being acutely sagittiform.

Pectus and femora, and inner margin of hindwings densely clothed with rather long hair; more so in $f$ than in $q$.

Judging from the description and figure (loc. cit.) of $L$. cordata, the of of that species and $L$. nubifer differ but very slightly on the upperside, the former having the two hindmarginal spots of the hindwing indistinct and without green centre; but on the underside the difference is very great, $L$. cordata having the entire ground-colour white, with attenuated white-centred brown markings, 
agreeing pretty nearly with those presented by $L$. antinorii, Oberth., and L. poggei, Dewitz. The underside markings of $L$. nubifer are, in the forewings, very like those of $L$. lingeus (Cram.), but those in the hindwings are nearest to the corresponding ones in $L$. poggei, although in development, partial confluence, and disposition of colouring, they bear a strong general resemblance to those of $L$. lingens. The dull ochreyyellow field of the underside of the forewings is a very peculiar feature of $L$. nubifer, but a very faint basal indication of it seems to be shown by $L$. cordata.

The $q q$ of antinorii, poggei, and cordata are not described; that of nubifer is quite unlike the of lingeus, and, on the upperside, is in pattern very like the $f$ Lycænesthes liodes, Hewits., though so very dissimilar in ground-colour. The violaceous gloss over the dull ochrey-yellow tint of the forewings has a remarkable effect, recalling the appearance of the $\hat{\delta} \hat{\sigma}$ of the European Chrysophanus helle, and the New Zealand C. boldenarum.

This very distinct Lycæna-whose nearest ally, $L$. cordata, inhabits Sotik in Kavirondo, near the eastern shore of Lake Nyanza-was sent to me by Mr. A. E. Hunt, who wrote that he captured a pair near Newcastle (alt. circ. 3,800 ft.), in the northern extremity of Natal, on the 29th October, 1893, and a few others before the 12th December. Eleven more examples were taken about thirty-five miles to the southward, in the Biggarsberg-one at Waschbank, at the foot of the range, on the 14th January, and the others on the mountains themselves, between the 28th January and middle of February. Only one of the eighteen examples met with was in good condition, owing to the exceptionally wet season. Mr. Hunt notes the butterfly as flitting slowly from flower to flower of a species of acacia, and settling very frequently. He roused most of the specimens by rapping the branches with a, stick. On sending an example to Mr. C. W. Morrison, of Estcourt, Natal, that gentleman wrote to $\mathrm{Mr}$. Hunt that his collection contained a very worn specimen, captured by himself at Van Reenen's Pass in the Drahensberg, in March, 1886. He noticed a good many tattered examples frequenting the flowers of a weed, since identified by Mr. J. Medley Wood as Bidens pilosa, L. 
Hab. Natal, Newcastle and Biggarsberg (A. E. Hunt); "Van Reenen's Pass, Drakensberg," C. W. Morrison.

Capys disjunctus, sp. n. (Plate V., figs. 5, 5a.)

Exp. al. (ô) 1 in., 7-8 lin.; ( $q$ ) 1 in., 7-11 lin.

o. Sub-metallic orange-red; forewing with a narrow costal and moderately wide hindmarginal fuscous border; hindwing with a linear fuscous hindmarginal edging, and a greyish-fuscous costal and apical border, of moderate width, as far as extremity of 2 nd subcostal nervule. Forewing: inner margin rather broadly fuscous on its basal two-fifths; costal border of pretty even width, bounded inferiorly by subcostal nervure; hindmarginal border, in one example, of even width throughout, and irregularly dentate on its inner edge, but, in the other, narrowing considerably to posterior angle, and with its inner edge regular. Hindwing: base rather broadly fuscous; sexual patch at origin of subcostal nervules small, ovate, pale grey, glistening; inner marginal border broadly pale grey, densely hairy towards anal angle; a red spot on anal angular lobe. Cilia basally red, outwardly white, with fuscous nervular interruptions. UNDERSIDE : Pale ashy-grey, inclining to hoary; in forewing a broad basi-innermarginal space of pale ochreyellow; in both wings a rather indistinct dull ferruginous terminal disco-cellular annulet, and a discal series of similar annulets. Forewing : yellow space much paler near inner margin-the whole of which it occupies-and extending a little above median nervure ; indistinct discal annulets 5 or 6 , imperfect, partly confluent, forming a regular slightly-curved series from costa to 2 nd or 1st median nervule; a submarginal series of very indistinct darker grey marks. Hindwing : discal series of nine annulets strongly sinuated, the second and largest annulet united to terminal disco-cellular one, the fourth, fifth, and sixth smaller than the rest, more separate, and furthest from base; a very indistinct submarginal darker grey clouding.

9. Strikingly different from ô. Dull pale brownish-grey, paler discally (in one example with a very faint orange tinge superiorly), and suffused broadly from bases with pale greyish-blue; hindwing with four hindmarginal orange lunules. Forewing: base tinged with dusky-violaceous; a very faint thin terminal disco-cellular dark grey lunule. Hindwing: space above cell free from blue suffusion; cell near base tinged with dusky-violaceous; orange lunules distinct, forming a continuous series between radial nervule and submedian nervure, and bounded outwardly by a fuscous line. UNDERside: Hoary-grey, much paler than in of, 
with the markings much more distinct; only the faintest tinge of yellow over basi-innermarginal space in forewing. Forewing: an additional annulet (indistinct in one example) below 1st median nervule. Hindwing: hindmarginal lunules of upperside rather faintly represented in ferruginous-red. Palpi much shorterespecially the terminal joint-than in the $q$ C. alphous.

The $\delta$ is readily distinguished from that of $C$. alphæus by the much extended orange-red of the upperside, and consequent reduction of the hindmarginal fuscous border, especially in the hindwings. The $q$ is so extraordinarily unlike that of alphæus on the upperside that it might, at the first glance, be mistaken for a large $q$ Deudorix antalus (Hopff.). On the underside, however, there is no mistaking the characteristic pattern and coloration, which, in both sexes, although so very much duller and fainter, are entirely like those shown by the type of the genus Capys.

A faded example of the $\delta$, taken at Barberton, Transvaal, by Mr. C. F. Palmer, was lent to me in 1892 by Mr. A. D. Millar, and I then regarded it as a probable aberration of $C$. alphæus; not associating it with a damaged $q$ received during 1891 from Mr. F. C. Selous who had captured it in Mashunaland. When Mr. Millar, however, sent me a $q$ taken by him at Botha's Hill, Natal, on 6th January, 1894, and also again gave me the opportunity of examining Mr. Palmer's Barberton d , I came to the conclusion that these could only be regarded as sexes of the same species. This view received most welcome confirmation in June, 1894, when a pair reached me from Mr. G. A. K. Marshall, of Salisbury, Mashunaland, with the notification that he had taken corresponding specimens in copulâ.

Mr. Millar informs me that his $q$ of this species was taken on Botha's Hill, Inchanga, at an elevation of about 2,430 feet. This was the only specimen seen; it flew rapidly past him and settled with closed wings on a low flowering plant. Mr. Marshall writes that the $q *$ is considerably scarcer than the $\tilde{\delta}-\mathrm{I}$ have been struck with this in the case of C. alphaus-and that the of has the habit of resting on the dead calices (burnt by grass-fires)

On the 9th December, 1894, Mr. Marshall writes, however, that he had just lately noticed several specimens of the $q$ but none of the $\delta$. A dwarf $\delta$ captured by him in the Mazoe District, on 16th October, 1894, expands only 1 in. $4 \frac{1}{2}$ lin.

TRANS. ENT. SOC. LOND. 1895.-PART II. (JUNE.) 
of a dwarf sugar-bush, near Salisbury, and in that position is well concealed by the similar colouring of the underside of his wings.

The extreme dissimilarity in the females of two such similar males as those of $C$. alphrus and $C$. disjunctus is a most noteworthy phenomenon, and I do not recall another instance in the family Lycænidæ; although the converse case-that of very similar females of nearlyallied species having strikingly dissimilar males-is not rare. One is inclined to suspect that mimicry has come into play in the case of the $q C$. disjunctus.

Hab. Natal, Inchanga (A. D. Millar); Transvaal, Barberton (C. F. Palmer) ; Mashunaland, ? locality (F. C. Selous), Salisbury and Mazoe District (G. A. K. Marshall).

\section{Iolaus æmulus, sp. n. (Plate V., fig. 6.)}

Exp. al. (ô) 1 in., 3 lin.

Closely allied to I. aphnæoides, Trim.

§. Pale blue; apical half of forewing black ; cilia of forewing fuscous except at posterior angle where they are white, of hindwing wholly white. Forewing: costa evenly and rather widely bordered with black to extremity of discoidal cell; apical black area extending from extremity of cell to apex and obliquely to a point at posterior angle, its inner edge irregular; sexual tuft of bristles on inner margin near base, black. Hindwing: a narrow black edging from costa beyond middle, becoming linear and more sharply defined, and inwardly bordered by a white line, on hindmargin from 3rd median nervule to anal angle; two well-marked rounded hindmarginal black spots, one above, the other below, 1st median nervule, the lower spot internally edged by an indistinct yellowish lunule; a third black spot on anal angular lobe, ringed with a few greenish-silvery scales; basi-costal sexual patch better defined than in aphnceoides, glistening-grey in a darker ring. UNDERSIDE.-- White, with narrow red transversestreaks; a submarginal row of small black spots as in aphnooides. Forewing: an orange-red edging from base to posterior angle, linear on costa, but somewhat wider on hindmargin ; a very short red streak in discoidal cell near base, and a longer one marking extremity of cell ; beyond middle a rather oblique streak from costa to between 1st and 2nd median nervules; 7 spots in submarginal series, all very small except the two last, which are about twice the size of the rest and situate between 1st median nervule and submedian nervure; a large basi- 
innermarginal semicircular glistening sexual patch, extending to median nervure. Hindwing : a short oblique sub-basal streak from costal to median nervure ; a small sub-basal red spot close to inner margin; completely across wing, a streak from middle of costa to 1st median nervule considerably beyond middle, where it is slightly angulated and attenuated-thence to a point between that nervule and submedian nervure where it becomes black instead of red-and thence, widening and red again, at an acute angle as far as internal nervure about middle; six submarginal black spots (the 2nd larger than rest) from costa to 3rd median nervule-the series continued to inver margin by two disconnected short black lines, of which the superior is close to the sharp black angulation of the long discal red streak ; inferior hindmarginal black spot wanting, but superior one and spot on anal angular lobe, well developed, and widely bordered with greenish-silvery; hindmargin edged with orange-red from 2nd subcostal to 3rd median nervule, but thence to anal angle with a fine black line. Forehead orange-red; abdomen beneath white, with a median longitudinal red streak.

I have not seen the $q$, but, from a description accompanied by a careful coloured drawing of both upper and under sides made by Mr. A. E. Hunt, it is clear that in that sex on the upperside the blue is duller and basally clouded with fuscous, while the hindmarginal black is considerably broader at the posterior angle of the forewing, as is also the costal, apical, and upper hindmarginal black of the hindwing. The hindwing presents a small black hindmarginal spot between 2nd and 3rd median nervules (of which there is only the minutest trace in the $0^{\text {) }}$ and also three small blackish lunulate marks situate a little before the three hindmarginal spots. Above the latter, becween 3rd median and 2nd subcostal nervules, are two whitish spots. The underside markings agree with those of the $\delta$, except that in the hindwing there is some dusky-grey clouding along the hindmargin below the 3rd median nervule, and the upperside spot between 2nd and 3rd median nervules is indistinctly represented.

The of on the upperside closely resembles the of $I$. aphnroides, but the apical black area in the forewing is even broader, and the sexual patch in the hindwing rounder and better defined. The of evidently wants almost entirely the wide discal white shown on the upperside of both wings in the + aphnæoides, and has the black of the forewings much broader superiorly, and 
the submarginal series of blackish spots in the hindwings incomplete. On the underside both sexes of $I$. æmulus are well distinguished by the not only very much narrower but also quite differently coloured-red, instead of orange-ochreous and black-edged-transverse streaks, and by those of these markings that are sub-basal and disco-cellular being reduced to short widely-disconnected portions, instead of constituting continuous bands (from costal edge of the forewings) common to both fore and hindwings. The conspicuous feature common and peculiar to aphnæoides and rmulus on the underside is the submarginal series of small black spots in both wings.

Mr. A. E. Hunt sent me his description and drawing of the $q$ in March, 1893, and noted that the only specimen he had seen was found by a child on the Blackburn estate near D'Urban, Natal. I was disposed to think that the specimen depicted might be an aberration of I. aphnæoides,* until the arrival, in March, 1894, of the fine 0 above described, which was captured on the Berea, D'Urban, by Mr. A. D. Millar, on the 17 th November, 1889. Mr. Millar writes that this example was settling on the leaves of a creeper covering the bush at the side of a road; it took a short flight before it re-settled and was captured, and examination showed that it was not $I$. sidus, which on the underside it much resembled. No second specimen has been seen by either observer.

Hab. Natal, D'Urban (A. E. Hunt and A. D. Millar).

See Proc. Zool. Soc. Lond., 1894, p. 54, foot-note.

\section{Explanation of Plate V.}

Fig. 1. Ypthima mashuna, sp. n., $q$.

2, 2a. Mycalesis selousi, sp. n., ô, + .

3, 3a. Acrcea induna, sp. n., ô, + .

4, 4a. Lycana nubifer, sp. n., §, + .

5, 5a. Capys disjunctus, sp. n., ơ, + .

6. Iolaus cemulus, sp. n., of. 
Trans. Ent. Soc Lond. 1895. PL.V.
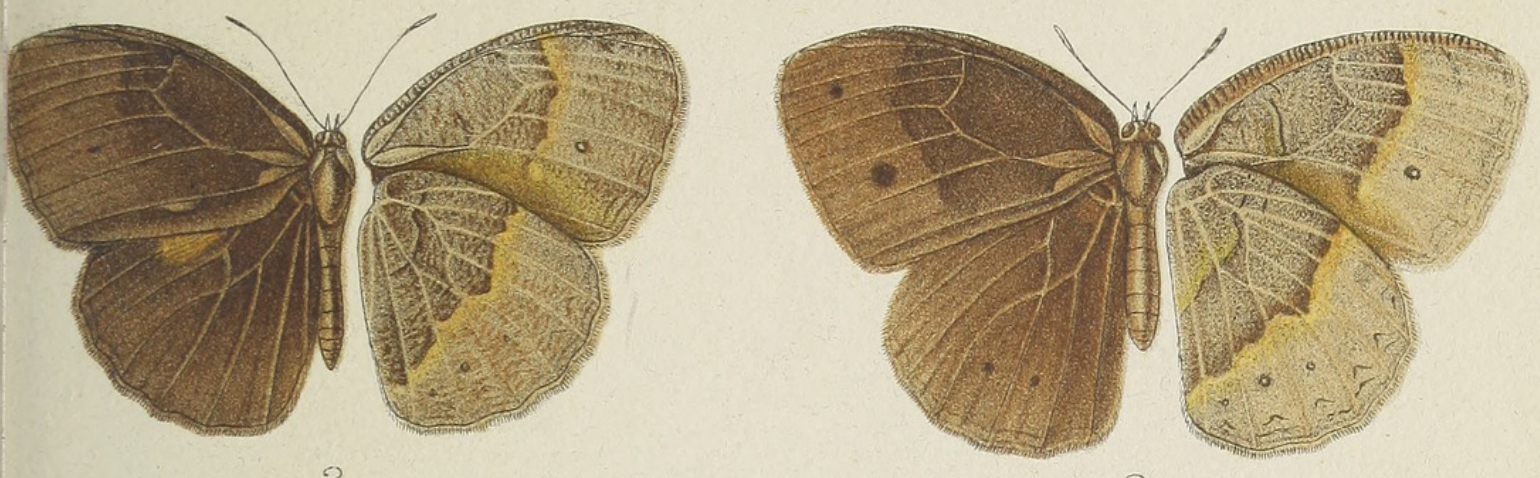

2

$2 a$

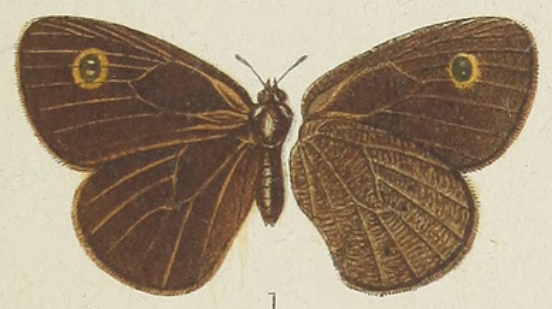

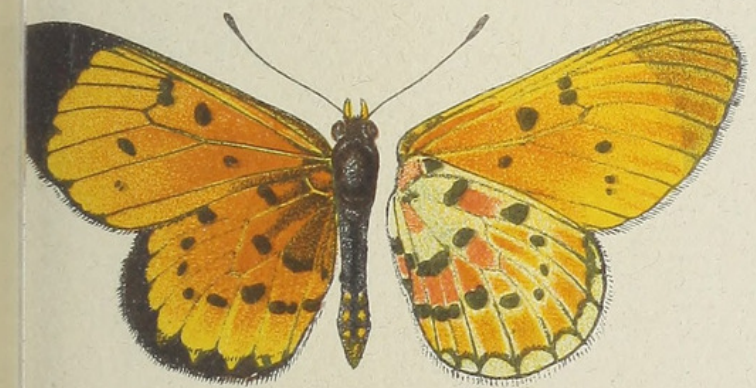

3

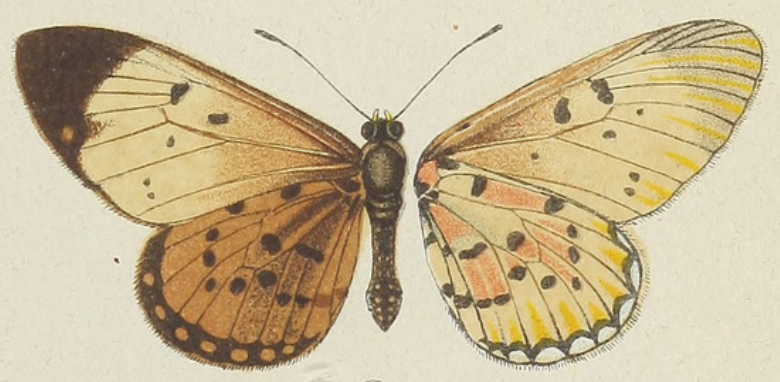

$3 \alpha$

4

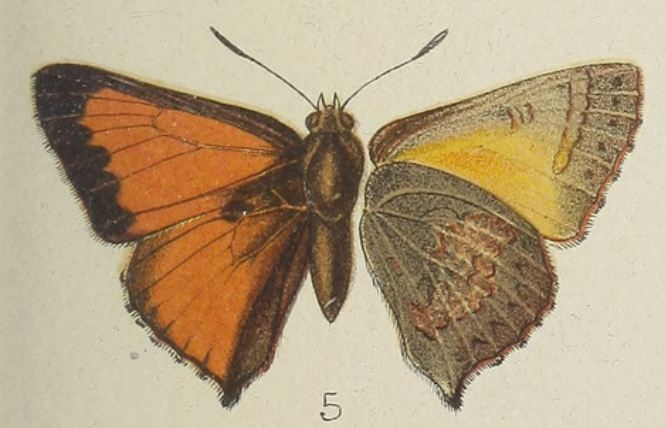

Arthur Rich del.
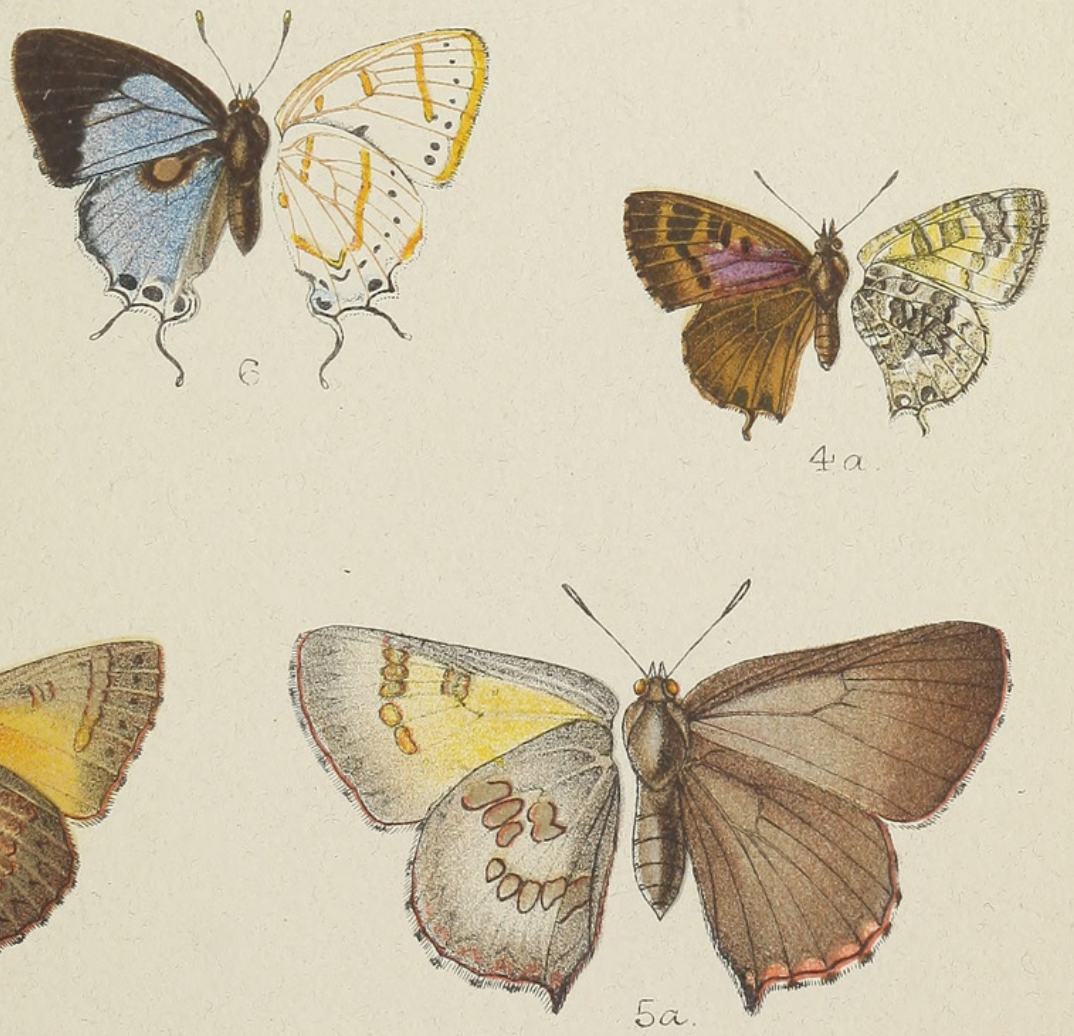

West, Newman chromo

New Species of South Africari Butterflies. 


\section{$2 \mathrm{BHL}$ Biodiversity Heritage Library}

1895. "VII. On some new species of Butterflies from Tropical and Extra Tropica1 South Africa." Transactions of the Entomological Society of London 43, 181-194. https://doi.org/10.1111/j.1365-2311.1895.tb01669.x.

View This Item Online: https://www.biodiversitylibrary.org/item/183290

DOI: https://doi.org/10.1111/j.1365-2311.1895.tb01669.x

Permalink: https://www.biodiversitylibrary.org/partpdf/22888

\section{Holding Institution}

Natural History Museum Library, London

\section{Sponsored by}

Natural History Museum Library, London

\section{Copyright \& Reuse}

Copyright Status: Public domain. The BHL considers that this work is no longer under copyright protection

This document was created from content at the Biodiversity Heritage Library, the world's largest open access digital library for biodiversity literature and archives. Visit BHL at https://www.biodiversitylibrary.org. 